\title{
Global data issues raised at IASSIST's 17th annual conference
}

"Data in the Global Village: Stewardship of an Expanding Resource," the central theme of the 17th annual conference of the International Association for Social Science Information Service and Technology (IASSIST), expressed IASSIST members' concerns for managing and sharing computerreadable data gathered on a wide range of issues facing our global community. The theme also touched upon the need to care for and preserve an ever-expanding volume of computer-readable data.

IASSIST members have been in the business of acquiring, processing, administering, preserving, and distributing computer-readable data since 1974 . Among its members are data librarians and archivists, information specialists, social scientists, researchers, computing personnel, planners, and administrators from government and private sectors. IASSIST conferences are stimulating because of the dialogue which is promoted amongst the varied attendees both during the formal presentations and during breaks and unstructured time.

Held in Edmonton, Alberta, from May 14-17, 1991, this year's program was particularly relevant for academic and research librarians. The plenary sessions, concurrent sessions, round table discussions, and workshops highlighted the divergent approaches to providing services for computerreadable social data and the convergent interests of the international participants.

The first plenary session, "Global Environmental Change: Data Problems and the Social Sciences," presented by David Rhind, Economic and Social Research Council, Scotland, focused on the urgency of understanding global environmental change and the variety of environmental change data which will be collected.

The second plenary session, "Data in the Archival Village," gave both U.S. and Canadian perspectives on issues relating to managing archival programs for electronic records. There are many hurdles to overcome at the national level to identify and acquire electronic records. Much support is needed to meet the archival agendas set forth by the speakers.

The third plenary session, "National and International Statistical Systems," featured speakers from the Statistical Services Branch of the United Nations, Statistics Canada, the Central Laboratory for Social and Economic Measurement in the Russia, and the Economic and Social Research Council Data Archive at the University of Edinburgh, Scotland. Problems with counting the global village as well as the current state of various national and international social statistics were discussed.

The concurrent sessions included these topics: remote access and new user services, new data description systems, evaluation and appraisal of machine-readable data files, text file issues for research and teaching, institutional responses to data access issues, special data collections on global change, archival standards of optical media, new software/hardware applications for data libraries, data from the source: the data producers, birthing pains of data libraries, electronic products and depository library programs, international publicuse microdata files, designing and producing your own CD-ROM, historical data collections, and finding the path to distributed computing with centralized data.

Of particular interest to librarians was the session on "BirthingPains of Library Data Services." Gaetan Drolet, Université Laval, shared his experiences as a newcomer. His talk, "DATA + LIBRARIAN = DATA LIBRARIAN?" emphasized the challenges he faces moving from the responsibilities as a social science librarian to those of a data librarian. E. Christine Hayward, University of Calgary, discussed a proposal for a data library service at Calgary. The library recognizes data service as part of its mandate to provide access to public information. Doug Poff, University of Alberta, spoke about Alberta's strategic library plan which centers on becoming a "virtual library" whereby a range of remote services and resources will be available through networks. The focus of academic libraries will truly shift from institutional ownership and self-sufficiency to reciprocal access to research collections including data and other informational resources.

"Institutional Responses to Data Access Issues" provided an opportunity for discussion on changes in library school curricula in response to data access needs, data resource projects and programs of the Research Libraries Group, and data access issues in the decentralized '90s. Judith Rowe, Princeton University, pointed out that many academic institutions have a computing czar who is as likely to be a librarian in charge of "computing and information" as a computer scientist. Jim Coleman, Research Libraries Group, spoke about RLG's recent efforts to raise the general awareness of its membership to data resources and services and about RLG's future activities in this area.

(Cont. on next page) 
to reimburse the institution for such use under the guidance of institutional policy.

II.E.3.b. No staff member should use at home any object or item that is a part of the library's collections or under the guardianship of the library, or use any other property, supplies, or resources of the library except for the official business of the institution. To the extent that circumstance or special policies warrant exceptions, the circumstances or policies should be a matter of written record.

\section{II.F. Confidentiality}

Special collections librarians, whose work in- volves intimate knowledge of the work of researchers, the library's relations with donors and booksellers, and other material of a confidential nature, must be scrupulous in keeping this information confidential.

II.F.1. Special collections librarians must keepconfidential information about the activities and research of their readers which they gain in performance of their professional duties.

II.F.1.a. Exceptions may be made to this provision in cases where, for the advancement of scholarship, the reader has signed a written agreement to waive any claim to confidentiality in general or in specific instances.

\section{(Scholars cont. from page 720)}

The roundtable meeting ended with a discussion on how the future may be influenced. A number of scholars presented plans for projects that would create electronic publications available for shared access. Among these are the American Association for the Advancement of Science's online medical journal, a computerized dictionary of American literary terms, and a database of astronomy literature with natural language indexing. Common to these projects are the post-publication issues of storage, physical copies made at some point in time, and archival and preservation issues.

Academic librarians are already facing these access and archival issues with established programs at a number of large research institutions. They are positioned to play a key advisory role, guiding publishers and scholars in the design of electronic products that take into consideration the information needs of future generations who will use the scholarly information we are recording and distributing today.-Patricia E. Sabosik, Editor d Publisher, Choice

\section{(IASSIST cont. from previous page)}

In the session on text file issues, John PriceWilkins, University of Michigan, gave a paper on "Text Files in Libraries: Present Foundations and Future Directions." He stressed that users of text need generalized data suitable for use with a variety of software tools, as well as access to these resources in a networked environment. Research libraries have a responsibility to build electronic collections conformant with evolving standards for text encoding and to facilitate access to these resources outside the library. The session closed with an impressive demonstration of a system developed at UM to provide access to text files.

"Electronic Products and Depository Library Programs" was another session where academic librarians presented views on providing data services within a library context. Ray Jones, University of Florida, a long-time advocate of library involvement with providing access to census data regardless of format, shared his experiences with providing services over a period of two decades. Juri Stratford, University of California at Davis, highlighted the advantages and disadvantages of U.S. depository libraries receiving a deluge of electronic products, largely numeric, on CD-ROM.

Another hallmark of IASSIST conferences is the workshops. Four half-day sessions were offered and included "Starting a Data Library," "Living with UNIX," "Financial Time Series," and "Using Interactive Graphics and Statistical Data in the Classroom." Led by Ilona Einowski, University of California at Berkeley, and Jean Stratford, University of California at Davis, the workshop on "Starting a Data Library" raised many questions for those attending. While there is no one solution or organizational structure for data libraries, the various activities involved in organizing and operating a data library were debated by participants.

I attended the conference with the support of the ACRL Professional Liaison Committee and my home institution. As a member of the IASSIST Program Committee I worked to promote academic libraries as partners in providing access to computer-readable text and social data. The academic librarians who attended the conference and presented papers assisted in reaching that goal.Diane Geraci, social science and data librarian. State University of New York at Binghamton 